\title{
Krzysztof Walczak
}

Akademia Kaliska

im. Prezydenta Stanisława Wojciechowskiego

e-mail: krzysztof.walczak@op.pl

(iD) https://orcid.org/0000-0001-7581-2730

\section{Profesor Hanna Tadeusiewicz \\ i jej miejsce w biografistyce bibliologicznej}

\author{
DOI: https://doi.org/10.18778/0860-7435.31.02
}

\begin{abstract}
Abstrakt: Artykuł dedykowany jest łódzkiej uczonej prof. Hannie Tadeusiewicz. Jej działalność naukowa, dydaktyczna i organizacyjna związana jest z Uniwersytetem Łódzkim. Działania Pani Profesor były skoncentrowane na organizacji i wieloletniej kontynuacji prac nad warsztatem Słownika pracowników ksiqż̇ki polskiej. Swoje doświadczenia biografistyczne wykorzystała również w Kaliskim Towarzystwie Przyjaciół Nauk. Artykuł omawia osiągnięcia Pani Profesor w dziedzinie biografistyki. Kładzie szczególny nacisk na zasługi badaczki w dziedzinie bibliologii.
\end{abstract}

Słowa kluczowe: Hanna Tadeusiewicz, nauka, biografistyka, bibliologia

Bene merita - tak można streścić lata pracy naukowej i dydaktycznej prof. Hanny Tadeusiewicz, długoletniej pracowniczki Uniwersytetu Lódzkiego, całe swoje życie zawodowe głęboko związanej z tą instytucją i z rodzinna Łodzią. Urodzona w tym mieście, ukończyła studia polonistyczne na Wydziale Filologicznym Uniwersytetu Lódzkiego, uzyskując 5 lipca 1963 r. tytuł magistra. Wkrótce też podjęła pracę w Bibliotece Głównej Uniwersytetu Lódzkiego, pierwotnie wykonując prace zlecone, zaś od 1 października 1965 r. podejmując etatową pracę w tej instytucji. Jej pierwszym miejscem zatrudnienia był Oddział 
Prac Naukowych, w którym spędziła blisko dwadzieścia lat, biorąc udział w pracach redakcyjnych formującego się w tych latach Stownika pracownikón ksiałki polskiej, wchodząc w skład redakcji i komitetu redakcyjnego tego wielkiego przedsięwzięcia, prowadzonego przez dziesiątki lat przez łódzkie środowisko bibliologiczne ${ }^{1}$. Oddziałem tym Hanna Tadeusiewicz kierowała w latach 1978-1983.

Praca w bibliotece nie była jedynym zajęciem w tym czasie, bowiem wkrótce po podjęciu tych obowiązków młoda bibliotekarka rozpoczęła zbieranie materiałów do przygotowywanej dysertacji doktorskiej. Efektem tych działań była obrona, w dniu 24 kwietnia 1970 r., pracy zatytułowanej Crasopisma warszawskie z lat 1825-1830 jako obraz zycia literackiego stolicy przed powstaniem listopadowym, w wyniku czego Hanna Tadeusiewicz uzyskała stopień doktora nauk humanistycznych w zakresie literatury polskiej nadany jej przez uchwałę Wydziału Filologicznego Uniwersytetu Łódzkiego. Obrona ta, przeprowadzona zresztą w znakomitym stylu, została częściowo utrwalona w interesującym dokumencie filmowym, poświęconym Uniwersytetowi Łódzkiemu, w którym Hanna Tadeusiewicz występuje, przestawiając tezy swojego doktoratu.

Ze względu na specyfikę działu Biblioteki Głównej UŁ, zajmującego się działalnością naukowa, w którym pracowała, szybko też podjęła starania o uzyskanie tytułu bibliotekarza dyplomowanego, co nastapiło dwa lata po uzyskaniu doktoratu, kiedy 12 grudnia 1972 r. zdała egzamin państwowy.

Kolejnym etapem rozwoju kariery naukowej doktor Tadeusiewicz było uzyskanie - po złożeniu przed Radą Wydziału Filologicznego Uniwersytetu Łódzkiego kolokwium habilitacyjnego i zatwierdzeniu habilitacji przez Centralną Komisję Kwalifikacyjną do spraw Tytułów i Stopni Naukowych - stopnia doktora habilitowanego nauk humanistycznych w zakresie nauki o książce, co nastapiło 25 czerwca 1982. Fakt ten spowodował, iż już 1 grudnia 1983 r. dawna bibliotekarka otrzymała stanowisko docenta w Katedrze Bibliotekoznawstwa i Informacji Naukowej UŁ, rozpoczynając na szeroką skalę działalność dydaktyczną oraz organizacyjną. Jej umiejętności zarządzania doceniono, powierzając 1 października 1987 r. kierownictwo Katedry, którą to funkcję pełniła aż do 2009 r. Czas ten jest pamiętany jako niełatwe lata w dziejach tej najstarszej placówki uniwersyteckiego kształcenia bibliotekarzy (przede wszystkim

\footnotetext{
${ }^{1}$ Idea Stownika pracownikón ksiażki polskiej wyszła ze środowiska bibliotekarzy jeszcze w czasie trwania II wojny światowej i była wspierana - poprzez kształtowanie listy nazwisk osób objętych zainteresowaniem redakcji, jak również pierwsze prace autorskie - przez pierwsze lata przez wiele ośrodków akademickich w Polsce. Ostatecznie jednak organizacji prac redakcyjnych oraz edycji słownika podjął się ośrodek łódzki, m.in. ze względu na zaangażowanie Ireny Treichel, jak również decyzję władz Uniwersytetu Łódzkiego ustanawiającą redakcję Stownika w strukturze uczelni.
} 
ze względu na trudne warunki lokalowe i związane z tym liczne przeprowadzki instytucji), lecz wspominany dobrze za przyczyną specyficznej atmosfery życzliwości i spokoju, zawdzięczanej osobowym cechom Kierownika Katedry.

Działania administracyjne nie wyczerpywały obowiązków prof. Tadeusiewicz w Katedrze, bowiem był to również czas przekazywania wiedzy adeptom bibliotekoznawstwa poprzez liczne wykłady (szczególnie obejmujące szeroko pojętą historię książki), a także seminaria magisterskie, w trakcie których przygotowała do obrony i odebrania dyplomów ponad 150 magistrów. Na uwage zasługuje także wypromowanie przez prof. Tadeusiewicz sześciorga doktorów. Ich dysertacje w większości tematycznie powiązane zostały z problematyką biografistyki i regionalizmu. Do chwili obecnej Pani Profesor wciąż pozostaje cenionym recenzentem rozpraw doktorskich i habilitacyjnych, a także dorobku naukowego do wniosków o tytuły profesorskie.

Cechy osobowościowe, a także sprawność organizacyjna prof. Tadeusiewicz docenione zostały także przez Radę Wydziału Filologicznego Uniwersytetu Lódzkiego, która powołała ją do pełnienia obowiązków prodziekana tegoż Wydziału w ciagu dwóch kadencji, a zatem od 1 października 1990 do końca września 1996 r. Była też członkiem licznych komisji senackich Uniwersytetu Łódzkiego, zaś w latach 2003-2008 przewodniczyła Radzie Bibliotecznej Biblioteki Uniwersyteckiej w Lodzi.

Ukoronowaniem kariery naukowej było nadanie 22 grudnia 1994 r. Hannie Tadeusiewicz tytułu naukowego profesora nauk humanistycznych. W ślad za tym wydarzeniem ówczesna docent 28 października 1995 r. otrzymała mianowanie na stanowisko profesora nadzwyczajnego, zaś w dwa lata później (1 sierpnia 1997) - profesora zwyczajnego.

Ważnym elementem działań prof. Tadeusiewicz była praca w Komisji Egzaminacyjnej do przeprowadzania postępowania kwalifikacyjnego dla kandydatów na dyplomowanego bibliotekarza oraz dyplomowanego pracownika dokumentacji i informacji naukowej przy Ministrze Edukacji Narodowej. Swoja działalność w tej strukturze rozpoczęła w 1984 r., w latach 1996-1999 pełniła funkcję zastępcy przewodniczącego tej Komisji, a w latach 1999-2013 - przewodniczącego. Swoją misję sprawowała aż do likwidacji Komisji Egzaminacyjnej, co nastapiło na mocy ustawy „,deregulacyjnej” z lipca 2013 r.

Przez wiele lat Hanna Tadeusiewicz współpracowała z rozmaitymi instytucjami oświatowymi, m.in. prowadząc liczne zajęcia w ośrodkach kształcenia nauczycieli, zaś w 1993 r. została powołana przez Prezesa Polskiej Akademii Nauk na członka Rady Naukowej Biblioteki PAN w Warszawie, pełniąc tę funkcję do momentu likwidacji biblioteki w roku 2004.

Od lat profesor Tadeusiewicz działa w wielu stowarzyszeniach społecznych i naukowych. Ważnym polem takich działań jest Stowarzyszenie 
Bibliotekarzy Polskich, którego członkiem jest od roku 1969. W SBP pełniła funkcje w zarządzie Okręgu Lódzkiego i w Zarządzie Głównym w Warszawie, zaś potwierdzeniem jej zasług dla stowarzyszenia było nadanie jej w 1999 r. Honorowej Odznaki Stowarzyszenia Bibliotekarzy Polskich. Od 2000 r. wchodziła też w skład jury „Nagrody Młodych SBP” na najlepszą pracę magisterska, a od 2002 r. była członkiem Komisji SBP ds. Nagrody Naukowej im. Adama Łysakowskiego.

W 1984 r. Hanna Tadeusiewicz została członkiem Łódzkiego Towarzystwa Naukowego, by już od następnego roku objąć funkcję zastępcy przewodniczącego i sekretarza Wydziału I (Nauki Humanistyczne), pełnioną do 2003 r. Szczególnie ważnym wyróżnieniem było dla Niej od 2005 r. członkostwo w Komisji Historii Książki i Bibliotek Komitetu Nauk Historycznych Wydziału I Nauk Społecznych Polskiej Akademii Nauk. Od roku 1988 jest także członkiem Kaliskiego Towarzystwa Przyjaciół Nauk (założonego w 1987 r.).

Profesor Tadeusiewicz od roku 1970 jest także czynną członkinią Lódzkiego Towarzystwa Przyjaciół Książki, a od 1996 r. także Polskiego Towarzystwa Bibliologicznego.

Prowadzone przez lata badania naukowe ukształtowały w działalności twórczej Hanny Tadeusiewicz dwa obszary, wyraźnie widoczne w jej obszernej bibliografii prac i wypełnione dziesiątkami publikacji ${ }^{2}$.

Pierwszy nurt zainteresowań prof. H. Tadeusiewicz wiąże się z czasopiśmiennictwem literackim XIX wieku, czego efektem była praca doktorska $C$ q ${ }^{-}$ sopisma warsqawskie z lat 1825-1830 jako obraz zycia literackiego stolicy przed powstaniem listopadowym, stanowiąca dowód zainteresowania nie tylko zawartością omawianych periodyków, lecz także kwestiami ich edycji, co wyraźnie kierowało uwagę polonistki w stronę problemów nauki o książce. Jeszcze wyraźniej na owe zainteresowania wskazywały kolejne opracowania monograficzne periodyków z czasów Królestwa Kongresowego („Dziennik Warszawski”, „Chwila Spoczynku”, „Motyl”, „Dekameron Polski”), publikowane w „Roczniku Historii Czasopiśmiennictwa Polskiego” oraz „Rocznikach Bibliotecznych”.

Kolejnym obszarem zainteresowania prof. Tadeusiewicz czasopiśmiennictwem polskim była prasa fachowa, ze szczególnym uwzględnieniem prasy drukarskiej i księgarskiej. W publikowanych niemal co roku artykułach autorka omówiła wiele zapomnianych XIX i XX-wiecznych periodyków, poświęconych problemom wymienionych grup zawodowych. Sa to opracowania

\footnotetext{
2 Omówienia twórczości piśmienniczej Hanny Tadeusiewicz dokonano w oparciu o publikację Hanna Tadeusiewicz. Bibliotekarz i bibliolog. Bibliografia publikacji 1966-2004, przygotowana przez uczennicę Pani Profesor i jej pierwszą doktorantkę, prof. Ewę Andrysiak (2004). Druk został wydany przez Kaliskie Towarzystwo Przyjaciół Nauk z okazji nadania prof. Tadeusiewicz w 2004 r. członkostwa honorowego tego stowarzyszenia naukowego.
} 
monograficzne „Budzika” (1883), „Czcionki” (1872-1876), „Drukarza i Księgarza” (1897-1901), „Grafiki” (1912), „Ogniska” (1895-1900), „Pracy” (1878), „Pracownika Graficznego” (1928-1939), „Przeglądu Drukarskiego” S. Baylego, „Przewodnika dla Spraw Drukarskich i Litograficznych”; część z nich była podstawą ogłoszonej w 1982 r. rozprawy habilitacyjnej Drukarstwo polskie drugiej potowy XIX wieku w swietle fachowych czasopism drukarzy z. lat 1872-1900. Kilka artykułów, prezentujących zawodową i społeczną problematykę drukarstwa polskiego, prof. Tadeusiewicz poświęciła m.in. organizacjom drukarskim, kształceniu zawodowemu oraz innym elementom życia drukarzy i księgarzy.

Drugim nurtem prac prof. Tadeusiewicz pozostaja zainteresowania biografistyczne, nadające Jej sylwetce naukowej rys oryginalności. Z tą problematyka zetknęła się podczas pracy w Bibliotece Głównej Uniwersytetu Lódzkiego, gdzie, w momencie podejmowania przez nią działalności w Oddziale Prac Naukowych, istniał już zespół, kierowany przez Irenę Treichel ${ }^{3}$, uczestniczący w dziele tworzenia przyszłego Stownika pracowników ksiażki polskiej.

Idea organizacji i wydania tego dzieła powstała jeszcze w czasie II wojny światowej, zaś prace zapoczątkowane zostały w Państwowym Instytucie Książki w Łodzi w latach 1947-1948 i trwały, mimo rychłej likwidacji tej instytucji, w bibliotekach uniwersyteckich Torunia i Łodzi. Decyzja Rady Głównej Szkolnictwa Wyższego sprawiła, że idea słownika podjęta została przez kilka kolejnych bibliotek uniwersyteckich, ostatecznie więc zespoły takie powstały w bibliotekach Krakowa, Lublina, Lodzi, Poznania, Torunia, Warszawy oraz Wrocławia ${ }^{4}$.

Działania poszczególnych zespołów koordynowane były przez Komitet Redakcyjny, w skład którego wchodzili przedstawiciele poszczególnych ośrodków, zaś redakcji słownika podjał się trzyosobowy zespół, na czele którego stanął Ksawery Świerkowski ${ }^{5}$, jedną z pozostałych osób (obok Witolda Pawlikowskiego z Poznania) była Irena Treichel.

Jakkolwiek pomysł przygotowania i druku zeszytu próbnego słownika powstał w Wrocławskim Towarzystwie Naukowym (Świerkowski, Pawlikowski \& Treichel (red.), 1958, s. 7-8), to właśnie ośrodek łódzki stał się miejscem prac nad ostatecznym kształtem dzieła, a to za przyczyną działalności dr Ireny

\footnotetext{
${ }^{3}$ Znany jest skład tego zespołu w 1958 r.; w jego skład - obok Ireny Treichel - wchodziły: Zofia Hiszpańska, Janina Jaworska, Jadwiga Połońska, Wanda Rukóyżo, Wanda Święcicka i Lucyna Zakrzewska (Świerkowski, Pawlikowski \& Treichel (red.), 1958, s. 10).

${ }^{4}$ We Wrocławiu działały dwa niezależne od siebie zespoły słownika - w Bibliotece Uniwersyteckiej oraz Bibliotece Zakładu Narodowego im. Ossolińskich, działającej wówczas w strukturze Polskiej Akademii Nauk (Świerkowski, Pawlikowski \& Treichel (red.), 1958, s. 10-11).

${ }^{5}$ K. Świerkowski (1897-1979), bibliotekarz, bibliograf, historyk książki, bibliofil. Autor szeregu prac z zakresu historii książki, księgoznawstwa, bibliotekarstwa i bibliografii (Kłossowski, 1986, s. 214-215).
} 
Treichel, która przy pomocy współpracowników doprowadziła do ukazania się owego zeszytu próbnego ${ }^{6}$, a następnie - już w ścisłej współpracy z Hanną Tadeusiewicz - do wydania ostatecznej wersji Stownika pracowników ksiażki polskiej, co nastapiło w 1972 r. $^{7}$

Tom, stanowiący efekt ponad dziesięcioletniej pracy redakcyjnej, był w znacznej mierze, obok wielkiego udziału Ireny Treichel, także dziełem Hanny Tadeusiewicz, która, zatrudniona pierwotnie przy pracach redakcyjnych, wkrótce weszła nie tylko w skład osiemnastoosobowego komitetu redakcyjnego słownika, lecz także stała się jedną z trzech redaktorek, którymi obok niej pozostawały Irena Treichel oraz Anna Michalewska ${ }^{8}$.

Szczęśliwie edycja tomu słownika nie zakończyła prac nad biografistyką ludzi książki, bowiem niemal od początku prac redakcyjnych zakładano, iż dzieło będzie wydawane w systemie holenderskim, przewidującym możliwość druku kolejnych tomów. Prac tych nie przerwała także śmierć Ireny Treichel w 1987 r., zaś jej ostatnim dziełem, wydanym ze znacznym udziałem Hanny Tadeusiewicz był Suplement, opublikowany w 1986 r. ${ }^{9}$ Charakterystyczna dla Pani Profesor pracowitość i skrupulatność dały efekt w postaci opracowania redakcyjnego około 900 haseł oraz przygotowania 168 haseł autorskich w obu częściach dzieła, a przecież trzeba do tego dodać współdziałanie z dr Treichel przy przygotowaniu znacznego objętościowo i unikatowego w formie indeksu, obejmującego oba tomy.

W listopadzie 1990 r. docent Tadeusiewicz otrzymała nominację na stanowisko kierownika Pracowni Stownika pracownikón ksiażki polskiej. Fakt ten zbieg1 się z decyzją rektora Uniwersytetu Lódzkiego, przenoszącą redakcję S łownika... z Biblioteki Głównej UŁ do Katedry Bibliotekoznawstwa i Informacji Naukowej, co pozwoliło kontynuować prace nad kolejnymi tomami wydawnictwa w strukturze uniwersytetu. Efektem tego był kolejny tom słownika (oznaczony jako Suplement II), który ukazał się pod jej redakcja (z udziałem Bogumiła Karkowskiego) w 2000 r., przynosząc kolejne 32 hasła autorstwa Pani Profesor, a także Suplement III, opublikowany w 2010. W taki sposób redakcja Stownika

\footnotetext{
${ }^{6}$ Stownik biograficzny pracowników ksiażki polskiej. Zeszyt próbny ukazał się nakładem Ministerstwa Szkolnictwa Wyższego, lecz jako druk Łódzkiego Oddziału Państwowego Wydawnictwa Naukowego. Dwutysięczny nakład tej edycji przeznaczony był do szerokiej dystrybucji, zaś ciekawostką był wklejany przez redakcję druk zwrotny, z miejscem na wpisanie opinii na temat jakości poszczególnych biogramów.

${ }^{7}$ Prace nad tomem rozpoczęto w 1961 r. pod redakcją Ireny Treichel, która jednocześnie z podjęciem prac przyjęła na siebie obowiązki redaktora tego dzieła.

${ }^{8}$ Wszystkie trzy panie reprezentowały Bibliotekę Główną Uniwersytetu Lódzkiego.

9 Redakcję Suplementu Stownika pracownikón ksiażki polskiej tworzyły Irena Treichel oraz Hanna Tadeusiewicz, były także autorkami indeksu, obejmującego oba tomy Stownika.
} 
funkcjonuje do dzisiaj, w oparciu o wieloletnie doświadczenia zespołu kierowanego przez pania profesor i pod Jej dyskretną opieką.

Prace redakcyjne oraz warsztat Stownika... zawsze budziły zainteresowanie środowiska, świadomego wartości tego dzieła. Nic zatem dziwnego, że Hanna Tadeusiewicz na różnych forach wielokrotnie przedstawiała stan prac, wygłaszając referaty na sesjach naukowych w Kaliszu, Łodzi i Warszawie (w Bibliotece Narodowej oraz towarzystwach naukowych). Doświadczenia w pracy nad Stownikiem... i znajomość jego warsztatu spowodowały zaproszenie do wspólpracy z redakcją Polskiego Stownika Biograficznego i Encyklopedia Wiedzy o Ksiażce, a także redakcją Stownika badaczy literatury polskiej.

Zainteresowania biografistyką tłumaczą także inne działania naukowe, prowadzone przez prof. Hannę Tadeusiewicz. To artykuły biograficzne i biobibliograficzne, poświęcone wybitnym ludziom książki; nie sposób jednak nie zauważyć, że spod pióra autorki wychodziły wspomnienia dotyczące ludzi, których Pani Profesor znała i ceniła. To artykuły poświęcone m.in. Januszowi Kapuścikowi (1932-1999), Jadwidze Siniarskiej-Czaplickiej (1913-1986), Jerzemu Starnawskiemu, Bolesławowi Świderskiemu (1917-1998), Irenie Treichel (19181987), Helenie Więckowskiej (1897-1984), Jerzemu Włodarczykowi (19201997). Wspólnie z Ireną Treichel prof. Tadeusiewicz opublikowała w 1993 r. listę strat księgarstwa polskiego w czasie drugiej wojny światowej (Straty osobowe ksiegarstwa polskiego w latach 1939-1945), obejmująca 264 biogramy księgarzy i wydawców polskich. Charakteryzowała też - w „Biuletynie Głównej Biblioteki Lekarskiej” - ludzi środowiska lekarskiego poprzez ich kontakty z książka, w taki też sposób patrzyła na dzieje drukarstwa łódzkiego (od 1863 do 1945 r.), mocno akcentując wątki biograficzne (Tadeusiewicz, 1992a, 1999, 2002).

Na osobną uwagę zasługuje także działalność prof. Tadeusiewicz w Kaliskim Towarzystwie Przyjaciół Nauk, którego członkiem docent Tadeusiewicz stała się w 1988 r., a zatem w rok po powstaniu tego stowarzyszenia. Momentem, w którym znana i ceniona pracownica nauki zainteresowała się dopiero co powstałym towarzystwem naukowym, była bez wattpienia organizacja przez KTPN międzynarodowej konferencji naukowej (październik 1989), poświęconej setnej rocznicy urodzin Marii Dąbrowskiej. Hanna Tadeusiewicz wystąpiła tam w znakomitym towarzystwie wybitnych polonistów z referatem zatytułowanym „Książka i ludzie książki w «Dziennikach» Marii Dąbrowskiej”10.

10 Organizatorem konferencji był znawca biografii i twórczości Marii Dąbrowskiej - prof. Edward Polanowski (1937-1991), pierwszy prezes Kaliskiego Towarzystwa Przyjació1 Nauk, a wśród prelegentów znaleźli się m.in. Helena Cybienko z Moskwy, Tadeusz Drewnowski, Constantin Geambaşu z Bukaresztu, Janina Kulczycka-Saloni, Zdzisław Libera, Aleksander Lipatow z Moskwy, Lech Ludorowski, Włodzimierz Maciąg, Julian Maliszewski, Andrzej Mencwel, Tone Pretnar z Lublany, Jan Trzynadlowski. 
Ryc. 1. Docent Hanna Tadeusiewicz podczas Międzynarodowej Sesji Naukowej, poświęconej jubileuszowi stulecia urodzin Marii Dąbrowskiej. Kalisz, październik 1989

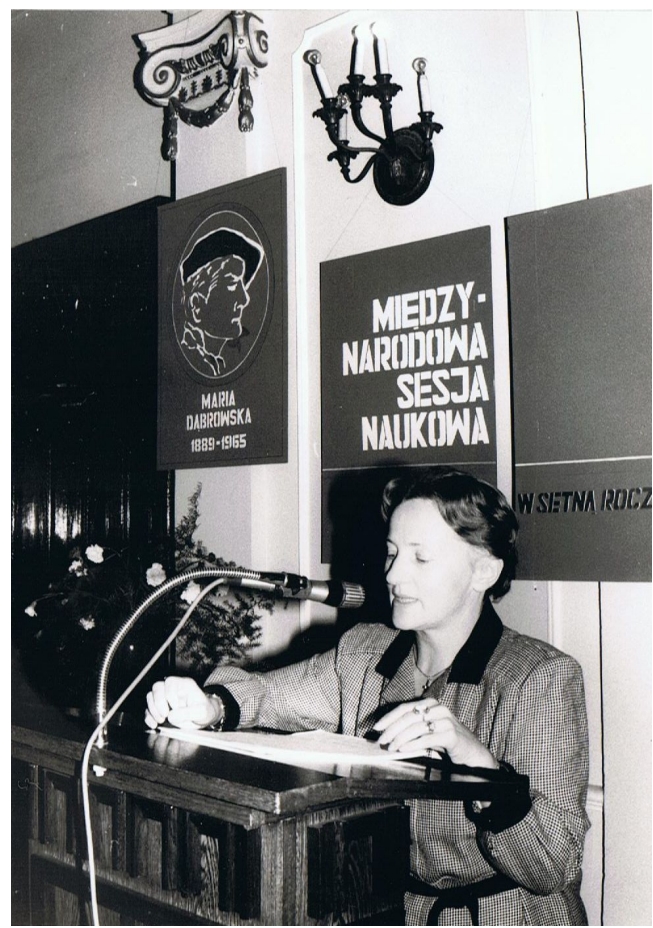

Źródło: Zbiory Kaliskiego Towarzystwa Przyjaciół Nauk

Już w grudniu 1989 r. prof. Tadeusiewicz przewodniczyła zespołowi redakcyjnemu, przygotowującemu bibliografię Kalisza i województwa kaliskiego, który to zespół w wyniku zmian układu administracyjnego państwa przerodził się w pracownię bibliografii miasta Kalisza. Efektem prac owej pracowni, działającej w strukturze towarzystwa, jest wydana w latach 2003-2007 Bibliografia historii Kalisza. Profesor Tadeusiewicz przewodniczy także Komitetowi Redakcyjnemu Stownika biograficznego Wielkopolski potudniowo-wschodniej, co nastąpiło po śmierci prof. Edwarda Polanowskiego, który rozpoczął prace nad tym dziełem. Pod redakcją Pani Profesor ukazał się w 1998 r. tom pierwszy Stownika biograficznego Wielkopolski poludniowo-wschodniej- ziemi kaliskiej, zawierający 468 haseł osobowych, zaś dzieło było kontynuowane pod redakcją dr Danuty Wańki (t. 2-3, 2003-2007) ${ }^{11}$.

\footnotetext{
11 Pracownia pod przewodnictwem prof. H. Tadeusiewicz kontynuuje prace nad czwartym tomem Stownika, redagowanym przez dr Bogumiłę Celer.
} 
Ryc. 2. Profesor Hanna Tadeusiewicz przewodniczy konferencji „Biblioteki pedagogiczne wobec wyzwań współczesnej oświaty”.

Kalisz 2007

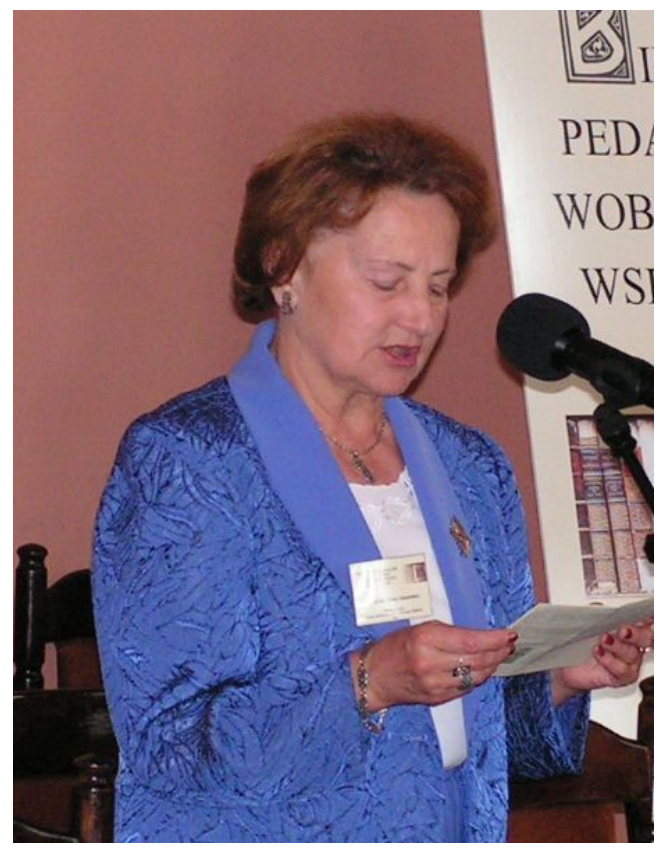

Źródło: Ze zbiorów Książnicy Pedagogicznej im. Alfonsa Parczewskiego w Kaliszu

Wspomnieć należy również o calisianach w dorobku Pani Profesor, a zatem publikacjach odnoszących się do wątków kaliskich. Są to artykuły zatytułowane: Marii Dabrowskiej świat ksiażki (1992b) oraz Ksiażka i ludrie ksiażki w „Driennikach” Marii Dabrowskiej (1996). W Stowniku pracowników ksiażki polskiej (Suplement I, 1986 i II - 2000) ukazały się także biogramy osób, związanych z książką kaliska pióra prof. Tadeusiewicz (Andrzej Lisiecki, Jan Nepomucen Sobczyński, Maria Dąbrowska).

Za to zaangażowanie w działalność Kaliskiego Towarzystwa Przyjaciół Nauk stowarzyszenie podziękowało przyznając w 2004 r. prof. Hannie Tadeusiewicz honorowe członkostwo KTPN ${ }^{12}$.

Dokonując swoistej oceny działalności naukowej prof. Hanny Tadeusiewicz wypadałoby zakończyć ją listą odznaczeń i nagród, jakie Pani Profesor

\footnotetext{
12 Honorem tym Kaliskie Towarzystwo Przyjaciół Nauk obdarowało w ciągu trzydziestu lat istnienia zaledwie osiem osób, w tym troje przedstawicieli bibliologii: prof. prof. Krzysztofa Migonia, Hannę Tadeusiewicz oraz Annę Żbikowską-Migoń.
} 
w swoim pracowitym, pełnym sukcesów życiu uzyskała ${ }^{13}$. Niech jednak za podsumowanie wystarczy docenienie jej przez macierzysty uniwersytet, któremu całe życie wiernie służyła, a który uhonorował ją swymi najwyższymi laurami - w 1995 Medalem 50-lecia Uniwersytetu Lódzkiego, w 1987 - Medalem Uniwersytet Łódzki w Służbie Społeczeństwa i Nauki, w 1986 - Złotą Odznaką Uniwersytetu Łódzkiego. Swoistym hołdem złożonym przez liczne grono współpracowników Hanny Tadeusiewicz będzie też Stownik pracownikón ksią̇ki polskiej, przez ostatnie dziesięciolecia nierozerwalnie wiążący się z Jej nazwiskiem.

\section{Bibliografia}

Andrysiak, Ewa (2004). Hanna Tadeusiewicz. Bibliotekarz $i$ bibliolog. Bibliografia publikacji 1966-2004. Kalisz: Kaliskie Towarzystwo Przyjaciół Nauk.

Kłossowski, Andrzej (1986). Świerkowski Ksawery Antoni. W: I. Treichel (red.), Stownik pracowników ksiazki polskiej. Suplement (s. 214-215). Warszawa-Lódź: Państwowe Wydawnictwo Naukowe.

Świerkowski, Ksawery, Pawlikowski, Witold \& Treichel, Irena (red.) (1958). Stownik biograficzny pracowników ksiażki polskiej. Zesqyt próbny. Lódź: nakł. Ministerstwa Szkolnictwa Wyższego.

Tadeusiewicz, Hanna (1992a). Jerzy Włodarczyk - życie i działalność zawodowa. Acta Universitatis Lodziensis. Folia Librorum, 3, 5-13.

Tadeusiewicz, Hanna (1992b). Marii Dąbrowskiej świat książki (w świetle „Dzienników” z lat 1914-1965). Acta Universitatis Lodziensis. Folia Librorum, 3, 51-76.

Tadeusiewicz, Hanna (1996). Książka i ludzie książki w „Dziennikach” [Marii Dąbrowskiej]. W: Ksiega kaliska. W stulecie urodzin Marii Dabrowskiej (s. 105-113). Kalisz: Kaliskie Towarzystwo Przyjaciół Nauk.

Tadeusiewicz, Hanna (1999). Bolesław Świderski (1917-1998). Acta Universitatis Lodziensis. Folia Librorum, 9, 5-7.

Tadeusiewicz, Hanna (2002). Profesor Janusz Dunin - w siedemdziesięciolecie urodzin. Acta Universitatis Lodziensis. Folia Librorum, 11, 3-6.

Tadeusiewicz, Hanna (red.) (1998). Stownik biograficzny Wielkopolski południowo-wschodniej - ziemi kaliskiej. T. 1: [A-Z]. Kalisz: Kaliskie Towarzystwo Przyjaciół Nauk.

Tadeusiewicz, Hanna (red.) (2000). Stownik pracowników ksiażki polskiej. Suplement II. Warszawa: Wydawnictwo SBP.

Tadeusiewicz, Hanna (red.) (2010). Stownik pracownikón ksiażki polskiej. Suplement III. Warszawa: Wydawnictwo SBP.

Treichel, Irena (red.) (1972). Stownik pracownikón ksiażki polskiej. Warszawa-Łódź: Państwowe Wydawnictwo Naukowe.

Treichel, Irena (red.) (1986). Stownik pracowników ksiażki polskiej. Suplement I. WarszawaŁódź: Państwowe Wydawnictwo Naukowe.

${ }^{13} \mathrm{Na}$ liście tej znajduje się m.in. Krzyż Kawalerski Orderu Odrodzenia Polski, Złoty Krzyż Zasługi i Medal Komisji Edukacji Narodowej, odznaka „Zasłużony Działacz Kultury”, a także liczne nagrody Ministra Nauki i Szkolnictwa Wyższego oraz Rektora Uniwersytetu Lódzkiego. 


\title{
Professor Hanna Tadeusiewicz and her place in bibliological biography studies
}

\begin{abstract}
The article was dedicated to professor Hanna Tadeusiewicz, a scientist from Lodz. Her scientific, didactical and organizational activities are connected with the University of Lodz. Her activities were focused on a particular field which was the workshop of the Dictionary of the Polish Book Labourers where she was a co-organizer and continuator. She also transferred her experience in biographical studies to Kalisz Society of Friends of Sciences.
\end{abstract}

The article discusses the Professor's achievements in the field of biography studies. It puts a particular emphasis on the researcher's merits in the field of book studies.

KEYWORDS: Hanna Tadeusiewicz, science, biography studies, bibliology 